\title{
Effect of Fertilizer Sources on Potato Yield and Yield Components under Acidic Soil Condition in Central High Lands of Ethiopia
}

\author{
Egata Shunka $^{1 *} \quad$ Ayalew Adela $^{2} \quad$ Abebe Chindi $^{1} \quad$ Kassaye Negash $^{1} \quad$ Gebremedhin W/giorgis ${ }^{1}$ \\ 1 .Ethiopian Institute of Agricultural Research, Holetta Agricultural Research Center, Horticultural Research \\ Division, Potato Research Program, Addis Ababa, Ethiopia \\ 2. Ethiopian Institute of Agricultural Research, Holetta Agricultural Research Center, Land and Water use \\ Management Research, Water Shed Research Program, Addis Ababa, Ethiopia
}

\begin{abstract}
Agronomic practices like fertilizer application and low soil $\mathrm{pH}$ which associated with soil infertility problems are considered to be among the major challenges to potato production in the highlands of Ethiopia. In response to this, an experiment was conducted to compare effect of different sources of fertilizes on potato yield and yield components from 2015-2016 main cropping season(June-August) in four districts of west and south west part of Ethiopia comprising two potato varieties Belete and Gudenie as main plot and five fertilizer source treatments as sub plot. These fertilizer source treatments were control, recommended Urea (165 kg/ha) and DAP (195 kg/ha), recommended Urea $(165 \mathrm{~kg} / \mathrm{ha})$ and DAP $(195 \mathrm{~kg} / \mathrm{ha})$ plus $225 \mathrm{~kg} / \mathrm{ha}$ potassium sulfate $\left(\mathrm{K}_{2} \mathrm{SO}_{4}\right)$, recommended Urea $(165 \mathrm{~kg} / \mathrm{ha})$ and DAP (195 kg/ha) plus $225 \mathrm{~kg} / \mathrm{ha}$ potassium chloride $(\mathrm{KCl})$ and $242 \mathrm{~kg} / \mathrm{ha}$ blended mineral fertilizer NPSB with $\mathrm{N}=18.9 \%, \mathrm{P}=37.7 \%, \mathrm{~S}=6.95 \%, \mathrm{~B}=0.1 \%$ content plus $141 \mathrm{~kg} / \mathrm{ha}$ urea under both limed and unlimmed soil conditions. The design was split plot with three replications. The data were analyzed using SAS soft ware versions 9.2. The experiment results showed that interaction of location and fertilizer types was highly significant in affecting total tuber and marketable tuber weight in $\mathrm{t} / \mathrm{ha}$. The Blended NPSB fertilizer was found superior in Welmera and Gumer location producing maximum total tuber yield of 33.21t/ha and 22.93t/ha respectively, under unlimmed soil condition while recommended urea and DAP provided maximum total tuber yield $31.38 \mathrm{t} / \mathrm{ha}$ and $24.06 \mathrm{t} / \mathrm{h}$ a under limed soil condition, respectively. In Jeldu growing location, the recommended urea and DAP plus $\mathrm{KCl}$ was produced maximum total tuber yield (19.13 t/ha under Unlimmed; and $23.9 \mathrm{t} / \mathrm{ha}$ total tuber yield under limed soil condition). In wenchi, the recommended urea and DAP was produced maximum 25.66 and $30.99 \mathrm{t} /$ ha total tuber yield under both un-limed and limed soil condition, respectively. Interaction of growing year and location was highly significant in influencing average tuber number (total tuber number/plant) and average tuber weight (total tuber weight/tuber number). Interaction of location and growing year was highly significant in influencing dry matter under un-limed and limed soil condition. From these results, it can be concluded that the growing location and fertilizer sources had significantly affected the yield and yield component of potato both under limed and unlimmed soil conditions.
\end{abstract}

Keywords: Potato, Potassium Fertilizer, Acid Soils, Lime Application

DOI: $10.7176 / \mathrm{JNSR} / 9-23-02$

Publication date: December $31^{\text {st }} 2019$

\section{INTRODUCTION}

Potato is one of the major food security and cash crops in Ethiopia. It is a nutritious, high-value, short production cycle crop, and one of the few available food sources in the highlands during the hunger months of July to November before harvest of grain crops. Potato produces more food per time, area and other resources than most major crops. Over a century and two decades, potato in Ethiopia grew from a garden crop in few regions to a staple crop produced in many regions and under different agro-ecological conditions. In the last few years, potato has continued to grow rapidly in importance for food security and income generation. The area under potato increased from 62,000 to 296,000 ha and production increased from 500,000 to 3.6 million tons from 2006 to 2016 . Productivity at a national level has increased from about $8 \mathrm{t} /$ ha to greater than $12 \mathrm{t} / \mathrm{ha}$, with average yields of progressive farmers well above 30t/ha (Gebremedhin et al., 2015, CSA, 2006 and 2016), but this yield is considered to be low compared to other countries. There are many factors that have been identified as the causes for this low yield in Ethiopia, among which the lack of proper nutrient management seems to explain most of the differential with the potential yields of the existing potato varieties. Moreover, potato is growing in nitisols where these soils are highly depleted of essential inherent nutrients and having soil acidity problem. Most of the agroecologies in Ethiopia have favorable climatic and edaphic conditions having a huge potential to produce high quality potatoes. Agronomic practices like fertilizer application remarkably influence potato crop emergence, the onset and area increase of leaves, canopy development and subsequent performance and tuber production. Potato as a high yielding crop, consumes more nutrients from the soil at a given time for better tuber production because the food produced through photosynthesis in plant leaves needs in translocation and synthesis of carbohydrates to 
form tuber.

Fertilizer use in Ethiopia has focused mainly on the use and application of nitrogen and phosphorous fertilizers in the form of di-ammonium phosphate (DAP) and Urea for almost all cultivated crops for both market and food security purposes for the last several years. Such unbalanced application of plant nutrients may aggravate the depletion of other important nutrient elements in soils such as $\mathrm{K}, \mathrm{Mg}, \mathrm{Ca}, \mathrm{S}$ and micro-nutrients. Although nitrogen, phosphorus and potassium are the three major nutrient elements required in large quantities for normal growth and development of potato tubers, some reports indicated that elements like $\mathrm{S}, \mathrm{Ca}, \mathrm{Mg}$ and micro-nutrients particularly $\mathrm{Cu}, \mathrm{Mn}, \mathrm{B}$, Mo and $\mathrm{Zn}$ are becoming depleted and deficient on major crops in different areas of the country (Abiye et al., 2001; Asgelil et al., 2007). As indicated by Abayneh et al. (2001), the soils of some of the regional and federal agricultural research centers such as Areka and Pawe were found to be deficient in $\mathrm{K}$ status. This is particularly apparent in areas where agricultural crop production makes use of the application of $\mathrm{N}$ and $\mathrm{P}$ fertilizers on a continuous basis. These fertilizers and the resultant high tuber and biomass yield depend on the heavy mining of $\mathrm{K}$ and even micronutrients of soil resulting in their rapid depletion.

Poor soil fertility is important factor limiting potato production and negative nutrient balance is a feature of Ethiopian soils due to poor state of replenishment of nutrients. Soil fertility depletion is the root cause of declining crop production in Africa with fertility depletion rates 7 times larger than fertilizer imports (Sanchez, 2000). 37 African countries lost 132 million $\mathrm{t}$ of $\mathrm{N}, 15$ million $\mathrm{t} \mathrm{P}$ and 90 million $\mathrm{t}$ of $\mathrm{K}$ from their cultivated lands during the last 30 years (Sanchez, 2000). In Ethiopia, both the rates of nutrient replenishment and the balance between $\mathrm{N}$ and $\mathrm{P}$ nutrients in the fertilizer applied are extremely inadequate. Potato is very intensive crop and requires Macro and Micro in organic nutrients at very high rate due higher dry matter production per unit area and time as compared to other field crops. Since most of the soils are poor in available nutrients in this days and the crop has shallow and sparse root system, nutrient demand is generally not met by soil.

One of the major production factors of potato is fertilization. Horticultural crops take potassium fertilizer in large quantities specially at fruit filling stage various source of $\mathrm{K}$ - salt are used such as Potassium chloride (Kcl), potassium sulfate $\left(\mathrm{K}_{2}-\mathrm{SO}_{4}\right)$, potassium nitrate $\left(\mathrm{KNO}_{3}\right)$ and mono-potassium sulphate $\left(\mathrm{KH}_{2} \mathrm{PO}_{4}\right)(\mathrm{Magen}, 2004)$. From those Macro and Micron inorganic fertilizers potassium $(\mathrm{K})$ is an essential plant nutrient that plays a very important role in potato plant growth and development. Its role is well documented in photosynthesis, increase enzymes activities, improving synthesis protein, carbohydrates, fats, enabling their ability to resist pest and disease. It enhance water uptake and root permeability and acts as a guard cell controller beside its role in increasing water use efficiency (Dkhil et al., 2011; Zakri and Obreza, 2009). The dynamics in climate change, resource management, and especially soil and crop management, is a most important factor in productivity, quality and lower costs of production. Potato based farming systems in Ethiopia are increasingly vulnerable to climatic variability and since potato cultivation involves intensive soil tillage, this leads to soil degradation by increasing the risk of erosion and leaching of nitrates and accelerating soil acidification. The maintenance of soil acidity $(\mathrm{pH})$ at a value appropriate for optimizing potato production is an important first step in soil management because soil $\mathrm{pH}$ affects soil properties, nutrient availability and plant nutrition. In order to maintain or increase the soil fertility, it is necessary to improve the soil condition by ameliorating the acidic soil and keeping balance the soil macro and micro elements. Therefore, this study was conducted for evaluating the effect of potassium $(\mathrm{K})$ from different source, mineral blends fertilizers, and recommended urea and DAPs fertilizers under acid soil condition with liming and un-liming the soil.

\section{MATERIAL AND METHODS}

\section{Site descriptions}

The study was carried out during 2015 and 2016 main cropping seasons on farmers' fields of four districts namely Welmera, Jeldu, Wenchi and Gumer. The sites are situated at $9^{0} 05^{\prime}, 57^{\prime}$ 'N $38^{\circ} 36^{\prime}$ '02' ' E (Welmera); N

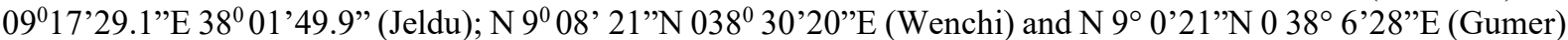
with altitude 2410, 2443, 2525 and 2998 masl for Welmera, Jeldu, Wenchi and Gumer, respectively. Composite soil samples were collected before planting for site characterization from $0-20 \mathrm{~cm}$ soil depth and analyzed for $\mathrm{pH}$, $\mathrm{P}, \mathrm{N}$, organic carbon (OC), $\mathrm{K}$, and cation exchange capacity (CEC)(Table 1). Plant sample was taken at time of flowering for nutrient analysis. Since the sites were acid soils, lime were applied on the basis of exchangeable acidity of each site determined in advance and applied one month before planting. The lime rates were 1.61, 6.57, 4.92 and 0.63 ton $\mathrm{ha}^{-1}$ at Welmera, Jeldu, Wenchi and Gumer, respectively. The Table 1 below showed, some chemical properties of the soil on which the potato was cultivated. 
Table 1: Soil sample analysis result before planting

\begin{tabular}{|c|c|c|c|c|c|c|}
\hline Location & PH & $\underset{\mathbf{p}}{\mathbf{P p m}}$ & $\% \mathrm{OC}$ & $\begin{array}{c}\mathrm{K} \\
\mathrm{meq} / 100 \mathrm{~g}\end{array}$ & $\% \mathrm{TN}$ & $\begin{array}{c}\text { CEC } \\
(\mathrm{Meq} / \mathbf{1 0 0 g})\end{array}$ \\
\hline $\begin{array}{l}\text { Welmera } \\
\text { unlimed }\end{array}$ & 4.69 & 7.18 & 1.83 & 1.03 & 0.18 & 19.22 \\
\hline Welmera limed & 5.25 & 7.54 & 1.83 & 0.90 & 0.19 & 18.50 \\
\hline Jeldu unlimed & 4.52 & 11.03 & 2.73 & 0.29 & 0.28 & 22.30 \\
\hline Jeldu limed & 4.59 & 12.18 & 2.92 & 0.29 & 0.33 & 23.32 \\
\hline Gumer unlimed & 4.99 & 2.37 & 2.73 & 0.64 & 0.39 & 26.10 \\
\hline Gumer limed & 4.96 & 2.38 & 2.85 & 0.72 & 0.39 & 26.06 \\
\hline HRC un limed & 4.77 & 5.79 & 1.32 & 0.72 & 0.16 & 22.40 \\
\hline HRC limed & 5.33 & 3.94 & 1.21 & 0.84 & 0.14 & 22.38 \\
\hline Wonchi un limed & 4.42 & 6.26 & 2.53 & 0.63 & 0.28 & 20.24 \\
\hline Wonchi limed & 4.56 & 15.56 & 2.61 & 0.60 & 0.25 & 20.24 \\
\hline Mean & 4.81 & 7.42 & 2.26 & 0.67 & 0.26 & 22.08 \\
\hline Test methods & $\begin{array}{l}1: 2,5 \\
\mathrm{H}_{2} \mathrm{O}\end{array}$ & $\begin{array}{l}\text { Bray } \\
\text { II }\end{array}$ & $\begin{array}{l}\text { Walkley } \\
\text { A.\&Black,I.A. }\end{array}$ & $\begin{array}{l}\text { Black,C.A } \\
\text { (flame } \\
\text { Photometer) }\end{array}$ & $\begin{array}{l}\text { Kjeldhal } \\
\text { bremner,J.M.\& } \\
\text { C.S. Mulvancy }\end{array}$ & Black,CA(Distillation) \\
\hline
\end{tabular}

\section{Experimental design, treatments and field operation}

Land preparation was uniformly performed across all sites and subsequent tilling operations were done by conventional tillage. Lime was evenly applied to treatment plots one month ahead of planting. A high quality limestone $\left(98 \% \mathrm{CaCO}_{3}, 99.5 \%<250 \mu \mathrm{m}\right.$ in diameter) was used. The amount of lime was applied calculated on the basis Al concentration of the site (Kamprath, 1984) assuming that one mole of exchangeable Al 3+ would be neutralized by equivalent mole of $\mathrm{CaCO}$ based on exchangeable acidity.

The experimental design was split plot with three replications having two potato varieties (Gudenie and Belete) as a main plot in each replication and five different fertilizer source treatments as sub plot with and without lime application. These fertilizer source treatments were control, recommended Urea (165 kg/ha) and DAP (195 kg/ha), recommended Urea $(165 \mathrm{~kg} / \mathrm{ha})$ and DAP $(195 \mathrm{~kg} / \mathrm{ha})$ plus $225 \mathrm{~kg} / \mathrm{ha}$ potassium sulfate $\left(\mathrm{K}_{2} \mathrm{SO}_{4}\right)$, recommended Urea $(165 \mathrm{~kg} / \mathrm{ha})$ and DAP (195 kg/ha) plus $225 \mathrm{~kg} / \mathrm{ha}$ potassium chloride $(\mathrm{KCl})$ and $242 \mathrm{~kg} / \mathrm{ha}$ blended mineral fertilizer NPSB( $\mathrm{N}=18.9 \%, \mathrm{P}=37.7 \%, \mathrm{~S}=6.95 \%, \mathrm{~B}=0.1 \%)$ plus $141 \mathrm{~kg} / \mathrm{ha}$ urea under both un limed soil conditions and limed soil condition with miner difference on control (no fertilizer but with lime under limed and with absence of both lime and fertilizer under unlimmed soil condition). The blended NPSB fertilizer was applied as basal application at planting to gather with DAP, potassium sulfate and potassium chloride while urea was applied half as basal and half after planting following randomization and replication procedure. Sprouted tubers of Belete and Gudenie potato varieties were planted on $3.75 \mathrm{cmx} 4.8 \mathrm{~cm}$ plot size at $10 \mathrm{~cm}$ planting depth. Other practices were done in the same practice as Holetta research center recommendation practice for potato production.

\section{Data Collection}

Tuber harvesting was done once at proper physiological maturity (75\% leaves withering). During harvesting tubers were categorized in to marketable and un-marketable yields. Marketable tubers were tubers which were greater than $20 \mathrm{~mm}$ in diameter and free of cracking, diseases, insect and mechanical damage. The plant height from the soil surface to the top most growth point of five (5) randomly selected plants from the middle rows of each treatment was measured using ruler at $75 \%$ of flowering which averaged in to one representative treatment plant height. The stem number is calculated from account of 5 planted tuber stem number average. The tuber dry matter was prepared from 500gm sample tubers by drying it in oven at $65^{\circ} \mathrm{c}$ temperature until constant dry weight was achieved. The data collected were total tuber and marketable yields in ton/ha, average tuber number/plant and weight/ tuber, Main stem number, unmarketable tuber weight, tuber dry weight in $\%$ and plant height in $\mathrm{cm}$ at maturity.

\section{Data Analysis}

Analyses of variance were performed using the SAS statistical program (SAS V9.2, SAS Institute Inc., Cary, NC, USA). Analyses of variance for tuber yield, done for all seasons and after pooling data over years. Whereas pooled over years data were analyzed for yield components. Whenever treatment differences were found to be significant, based on results of F-test, critical differences were calculated at 5\% level of probability using List Significance Difference (LSD) Test.

\section{RESULTS}

Average tuber number and weight: Interaction of growing yea and location, location and fertilizer source were 
highly significant in causing impact on both average tuber number and weight in the limed and un limed soil conditions (Table 2\&3) while growing environment and variety interaction was highly significant in affecting average tuber number per plant and weight only under limed soil condition and not significant under unlimmed soil condition.

Table 2: Year and location interaction effect on yield and yield component

\begin{tabular}{lllllll|lllll}
\hline \multicolumn{5}{c}{ Unlimmed } & \multicolumn{4}{c}{ Limed } \\
\hline Year & Location & ATN & ATW & DM & $\begin{array}{l}\text { TY } \\
\text { t/ha }\end{array}$ & $\begin{array}{l}\text { MY } \\
\text { t/ha }\end{array}$ & ATN & ATW & DM & $\begin{array}{l}\text { TY } \\
\text { t/ha }\end{array}$ & $\begin{array}{l}\text { MY } \\
\text { t/ha }\end{array}$ \\
\hline 2015 & Welmera & 5.77 & 123.75 & 25.58 & 26.85 & 10.13 & 9.79 & 118.44 & 23.94 & 25.50 & 15.32 \\
& Jeldu & 9.51 & 160.66 & 24.21 & 15.81 & 15.04 & 7.99 & 87.82 & 25.06 & 21.10 & 19.38 \\
& Wenchi & 9.22 & 68.75 & 22.83 & 23.88 & 23.11 & 8.77 & 65.04 & 24.27 & 25.59 & 25.21 \\
& Gumer & 7.74 & 57.36 & 24.21 & 14.87 & 13.27 & 8.98 & 75.71 & 22.81 & 11.74 & 10.78 \\
2016 & Welmera & 9.59 & 74.55 & 24.00 & 30.80 & 25.05 & 6.15 & 57.39 & 24.03 & 28.36 & 24.33 \\
& Jeldu & 7.66 & 49.35 & 20.25 & 15.54 & 13.33 & 10.01 & 80.03 & 17.31 & 18.51 & 15.49 \\
& Wenchi & 9.02 & 51.42 & 22.08 & 18.89 & 17.68 & 9.30 & 72.48 & 23.71 & 27.05 & 26.01 \\
\hline & Cv (5\%) & 22.11 & 23.71 & 24.65 & 22.11 & 27.72 & 9.1 & 10.19 & 6.37 & 14.45 & 23.67 \\
\hline & P-value & $<.0001$ & $<.0001$ & $<.0001$ & $<.0001$ & $<.0001$ & $<0.0001$ & $<0.0001$ & $<0.0001$ & 0.04 & 0.044 \\
\hline
\end{tabular}

$A T N=$ Average tuber number; $A T W=$ Average tuber weight in $\mathrm{g} /$ tuber; DM= Dry matter in $\%$; $C V=$ coefficient of variation, My t/ha=marketable tuber yield ton per hectare and total tuber yield ton per hectare.

The average tuber number/plant and weight per tuber was not significantly affected by interaction of variety and fertilizer sources (Table 4\&5). Under unlimmed soil, Jeldu growing location produced maximum average tuber number and weight in 2015 while Welmera produced maximum average tuber number and weigh in limed soil in the same year.

In 2016, Welmera growing location produced maximum average tuber number while Gumer growing location provided maximum average tuber weight in 2016 under unlimmed soil. Under limed soil condition Jeldu growing location provided maximum average tuber number and location in 2016.

Dry matter: interaction of location and growing year was highly significant in influencing dry matter under unlimed and limed soil conditions (Table 2) while the interaction of variety and location, interaction of fertilizer types and variety were highly significant under limed soil condition (Table 4 and 5). The highest dry matter was produced from Welmera location in both years under unlimed condition while the lowest was obtained from Wenchi in 2015 and Jeldu in 2016. Under limed condition, Jeldu location produced highest tuber dry matter in 2015 and Welmera in the 2016 growing year while lowest dry matter was registered from Gumer in 2015 and Jeldu in 2016 growing year. Belete variety planted in Welmera location yielded maximum tuber dry matter $(25.99 \%)$ while Gudenie in Jeldu provided minimum tuber dry matter $(21.83 \%)$.

Table 3: Location and fertilizer interaction effect on yield and yield component

\begin{tabular}{|c|c|c|c|c|c|c|c|c|c|c|c|}
\hline \multirow[t]{2}{*}{ Location } & \multirow[t]{2}{*}{ Fertilizer sources } & \multicolumn{5}{|c|}{ Unlimmed } & \multicolumn{5}{|l|}{ Limed } \\
\hline & & ATN & ATW & DM & $\begin{array}{l}\text { TTY } \\
\text { t/ha }\end{array}$ & $\begin{array}{l}\text { MTY } \\
\text { t/ha }\end{array}$ & ATN & ATW & DM & $\begin{array}{l}\text { TTY } \\
\text { t/ha }\end{array}$ & $\begin{array}{l}\text { MTY } \\
\text { t/ha }\end{array}$ \\
\hline \multirow[t]{5}{*}{ Welmera } & Control & 7.80 & 102.22 & 25.21 & 15.22 & 9.21 & 7.25 & 74.92 & 24.27 & 13.08 & 9.44 \\
\hline & Reco.N\&P & 7.49 & 104.09 & 24.54 & 31.3 & 19.05 & 8.07 & 88.83 & 24.42 & 31.38 & 24.15 \\
\hline & Reco.N\&P+K ${ }_{2} \mathrm{SO}_{4}$ & 7.81 & 121.02 & 26.07 & 31.95 & 19.07 & 9.65 & 76.52 & 24.08 & 29.93 & 23.01 \\
\hline & Reco.N\&P+KCl & 7.86 & 141.78 & 24.16 & 32.46 & 18.73 & 9.39 & 78.57 & 24.82 & 28.96 & 20.34 \\
\hline & NPSB+N (Urea) & 7.44 & 143.19 & 23.97 & 33.21 & 21.88 & 8.87 & 81.91 & 24.35 & 31.32 & 22.2 \\
\hline \multirow[t]{5}{*}{ Jeldu } & Control & 4.95 & 168.71 & 21.93 & 6.68 & 5.95 & 5.59 & 68.85 & 23.23 & 13.77 & 12.33 \\
\hline & Reco.N\&P & 8.98 & 168.74 & 22.37 & 16.32 & 14.6 & 8.09 & 61.25 & 22.02 & 19.78 & 17.44 \\
\hline & Reco.N\&P+K ${ }_{2} \mathrm{SO}_{4}$ & 9.67 & 53.13 & 22.58 & 17.83 & 16.23 & 8.57 & 68.96 & 22.43 & 22.35 & 18.66 \\
\hline & Reco.N\&P+KCl & 9.88 & 64. 88 & 21.82 & 19.13 & 17.6 & 9.03 & 67.73 & 22.60 & 23.9 & 21.2 \\
\hline & NPSB+N(Urea) & 9.43 & 63.8 & 22.45 & 18.43 & 16.54 & 8.44 & 57.62 & 21.22 & 19.22 & 17.54 \\
\hline \multirow[t]{5}{*}{ Wenchi } & Control & 5.12 & 61.24 & 22.88 & 8.71 & 8.2 & 4.95 & 64.75 & 24.75 & 11.78 & 11.4 \\
\hline & Reco.N\&P & 10.19 & 57.36 & 23.03 & 25.66 & 24.49 & 10.00 & 77.00 & 23.33 & 30.99 & 30.05 \\
\hline & Reco.N\&P+K ${ }_{2} \mathrm{SO}_{4}$ & 9.68 & 60.11 & 22.63 & 24.75 & 23.87 & 9.95 & 78.11 & 23.32 & 28.22 & 27.41 \\
\hline & Reco.N\&P+KCl & 10.05 & 71.57 & 22.03 & 24.37 & 22.89 & 9.75 & 78.04 & 22.53 & 29.84 & 29.17 \\
\hline & NPSB+N(Urea) & 10.56 & 61.25 & 21.70 & 23.44 & 22.52 & 9.84 & 80.65 & 23.18 & 30.75 & 30.03 \\
\hline \multirow[t]{5}{*}{ Gumer } & Control & 6.91 & 72.74 & 23.42 & 15.31 & 14.03 & 5.77 & 57.40 & 23.98 & 12.16 & 11.19 \\
\hline & Reco.N\&P & 8.63 & 69.11 & 21.88 & 22.19 & 20.11 & 8.95 & 77.87 & 23.63 & 24.06 & 22.75 \\
\hline & Reco.N\&P+K ${ }_{2} \mathrm{SO}_{4}$ & 9.14 & 102.22 & 23.03 & 21.02 & 18.86 & 8.22 & 66.21 & 22.48 & 21.24 & 20.24 \\
\hline & Reco.N\&P+KCl & 8.85 & 104.09 & 23.17 & 22.11 & 20.34 & 8.11 & 63.38 & 21.17 & 20.23 & 18.95 \\
\hline & NPSB+N(Urea) & 9.03 & 121.02 & 23.20 & 22.93 & 21.16 & 9.79 & 59.98 & 22.90 & 22.38 & 21.05 \\
\hline $\mathrm{Cv}(5 \%)$ & & 22.11 & 23.71 & 24.65 & 22.11 & 27.72 & 18.88 & 18.88 & 25.65 & 17.42 & 23.67 \\
\hline P-value & & 0.006 & NS & NS & 0.0002 & 0.0035 & 0.0019 & 0.0019 & $\mathrm{NS}$ & $<0.0001$ & $<0.0001$ \\
\hline
\end{tabular}

$\overline{\mathrm{ATN}}=$ Average tuber number; ATW=Average tuber weight in $\mathrm{g} /$ tuber; $\mathrm{DM}=$ Dry matter in $\%$; $\mathrm{TY}$ t/ha $=$ Total tuber yield ton per hectare; $\mathrm{MY}$ t/ha= Marketable tuber yield ton per hectare; $\mathrm{CV}=$ coefficient of variation and NS $=$ not significantly different

Total tuber yield: the interaction of growing location and year, location and fertilizer types was highly significant in influencing total tuber yield t/ha (Table 2 and 3 ) while the interaction of location and variety was significant 
under limed soil condition (Table 4). The highest total tuber yield t/ha (30.8t/ha) and (28.36t/ha) was obtained at Welmera under both un limed and limed soil condition in 2016, respectively while the lowest total tuber yield (14.87t/ha and $11.74 \mathrm{t} / \mathrm{ha}$ ) recorded at Gumer location in un limed and limed soil condition, respectively in 2015. The lower total tuber yield was produced by Gudenie variety while the higher total tuber yield $\mathrm{t} / \mathrm{ha}$ was provided by Belete variety under both limed and unlimed soil conditions. The higher tuber weight was produced in 2016 production season than 2015 under both limed and unlimed soil conditions. Blended fertilizr(NPBS) was found superior in Welmera location producing maximum total tuber yield of $33.21 \mathrm{t} / \mathrm{ha}$ under unlimed soil condition, while recommended Urea and DAP provided maximum total tuber yield $31.38 \mathrm{t} / \mathrm{ha}$ under limed soil condition.

In Jeldu, the recommended urea and DAP with $\mathrm{KCl}$ produced maximum total tuber yield of $19.13 \mathrm{t} / \mathrm{ha}$ under un-limed; and $23.9 \mathrm{t} / \mathrm{ha}$ under limed soil condition. In wenchi, the recommended urea and DAP was produced maximum total tuber yield of $25.66 \mathrm{t} / \mathrm{ha}$ under un-limed and $30.99 \mathrm{t} / \mathrm{ha}$ total tuber yield under limed soil condition. The Blended fertilizer (NPBS) was found superior in Gumer location producing maximum total tuber yield of $22.93 \mathrm{t} /$ ha under unlimed soil condition, while recommended Urea and DAP provided maximum total tuber yield $24.06 \mathrm{t} / \mathrm{ha}$ under limed soil condition. Under un-limed, the interaction of variety and fertilizer types was highly significant in affecting total tuber yield (t/ha) and significantly affected under limed soil condition (Table 5).

Marketable tuber Yield: - the interaction of growing location and year under unlimed condition, interaction of location and fertilizer types was highly significant in influencing marketable yield $\mathrm{t} / \mathrm{ha}$ (Table $2 \& 3$ ) under both soil conditions while the interaction of location and variety was significant only under limed soil condition(Table 4). The highest marketable tuber yield was produced at Welmera in 2016 growing locations followed by Gumer in 2016 and Wenchi in 2015 under limed soil condition while Gumer and Wench provided equally highest marketable yield in 2016 followed by Welmera 2016 and Wench 2015 under limed soil condition. The highest marketable yield was produced at Welmera location by application of NPSB + Urea under unlimmed soil condition and recommended urea and DAP under limed soil condition followed by recommended urea and DAP $+\mathrm{K}_{2} \mathrm{SO}_{4}$ Table 4: Interaction of growing environment and variety on yield and yield component

\begin{tabular}{lllllll|lllll}
\hline Location & \multicolumn{9}{c}{ Unlimmed } & \multicolumn{4}{c}{ Limed } \\
\cline { 2 - 13 } & Variety & ATN & ATW & DM & $\begin{array}{c}\text { TY } \\
\text { t/ha }\end{array}$ & $\begin{array}{c}\text { MY } \\
\text { t/ha }\end{array}$ & ATN & ATW & DM & $\begin{array}{c}\text { TY } \\
\text { t/ha }\end{array}$ & $\begin{array}{c}\text { MY } \\
\text { t/ha }\end{array}$ \\
\hline Welmera & Belete & 7.61 & 106.14 & 25.48 & 31.22 & 20.19 & 8.57 & 89.76 & 25.99 & 29.66 & 22.06 \\
& Gudenie & 7.76 & 92.16 & 24.11 & 26.43 & 14.99 & 8.72 & 70.54 & 22.78 & 24.21 & 17.59 \\
Jeldu & Belete & 8.19 & 279.39 & 23.43 & 18.55 & 16.78 & 7.52 & 76.11 & 22.77 & 22.08 & 18.88 \\
& Gudenie & 8.97 & 177.98 & 21.03 & 12.80 & 11.59 & 8.37 & 53.65 & 21.83 & 17.52 & 15.99 \\
Wenchi & Belete & 8.76 & 71.24 & 23.48 & 23.81 & 22.32 & 8.66 & 83.94 & 24.37 & 27.89 & 27.06 \\
& Gudenie & 9.49 & 106.14 & 21.43 & 18.96 & 18.48 & 9.14 & 67.48 & 22.47 & 24.74 & 24.17 \\
Gumer & Belete & 7.81 & 92.16 & 22.58 & 24.44 & 22.35 & 7.68 & 84.12 & 22.87 & 23.94 & 22.68 \\
& Gudenie & 9.22 & 279.39 & 23.30 & 16.98 & 15.62 & 8.65 & 45.82 & 22.80 & 16.10 & 14.99 \\
\hline Cv (5\%) & & 23.71 & 24.07 & 9.1 & 22.11 & 27.72 & 18.88 & 19.71 & 8.62 & 14.45 & 17.14 \\
\hline P-value & & NS & 0.0009 & NS & NS & NS & 0.0016 & 0.0008 & $<0.0001$ & 0.04 & 0.044 \\
\hline
\end{tabular}

ATN $=$ Average tuber number; ATW=Average tuber weight in $\mathrm{g} /$ tuber; DM=Dry matter in $\%$; $\mathrm{TY} \mathrm{t} / \mathrm{ha}=\mathrm{Total}$ tuber yield ton per hectare; MY t/ha= Marketable tuber yield ton per hectare; $C V=$ coefficient of variation and NS = not significantly different

The marketable yield advantage obtained due to the application of fertilizer over the control was $137.57 \%$ under unlimmed and $155.83 \%$ under limed soil conditions. In line with this, the highest marketable yield at Jeldu growing location was $17.6 \mathrm{t} / \mathrm{ha}$ and $21.2 \mathrm{t} / \mathrm{ha}$ under unlimmed and limed soil condition, respectively at application of recommended urea and DAP + KCL. 
Table 5: Effect variety and fertilizer sources on yield and yield component

\begin{tabular}{|c|c|c|c|c|c|c|c|c|c|c|c|}
\hline \multirow{2}{*}{$\begin{array}{l}\text { Fertilizer } \\
\text { sources }\end{array}$} & \multirow[t]{2}{*}{ Variety } & \multicolumn{5}{|c|}{ Unlimmed } & \multicolumn{4}{|c|}{ Limed } & \multirow[b]{2}{*}{$\begin{array}{c}\mathrm{MY} \\
\mathrm{t} / \mathrm{ha}\end{array}$} \\
\hline & & ATN & ATW & $\mathrm{DM}$ & $\begin{array}{l}\text { TY } \\
\text { t/ha }\end{array}$ & $\begin{array}{l}\text { MY } \\
\text { t/ha }\end{array}$ & ATN & ATW & DM & $\begin{array}{l}\text { TY } \\
\text { t/ha }\end{array}$ & \\
\hline \multirow[t]{2}{*}{ Control } & Belete & 5.73 & 99.49 & 23.33 & 12.24 & 10.13 & 6.02 & 82.29 & 23.60 & 16.59 & 13.50 \\
\hline & Gudenie & 6.67 & 62.23 & 23.39 & 10.72 & 8.57 & 6.58 & 60.63 & 23.43 & 15.09 & 12.91 \\
\hline \multirow[t]{2}{*}{ Reco.N\&P } & Belete & 8.69 & 143.61 & 23.74 & 27.23 & 22.65 & 8.64 & 97.55 & 23.51 & 33.04 & 28.69 \\
\hline & Gudenie & 8.95 & 95.66 & 22.18 & 20.51 & 16.49 & 9.72 & 64.36 & 22.38 & 27.21 & 23.66 \\
\hline \multirow{2}{*}{$\begin{array}{l}\text { Reco.N\&P } \\
+\mathrm{K}_{2} \mathrm{SO}_{4}\end{array}$} & Belete & 8.80 & 136.15 & 24.67 & 26.95 & 22.14 & 8.84 & 89.52 & 22.84 & 31.34 & 26.84 \\
\hline & Gudenie & 9.36 & 97.96 & 22.49 & 20.81 & 16.88 & 10.02 & 66.01 & 21.95 & 27.23 & 23.97 \\
\hline \multirow{4}{*}{$\begin{array}{l}\text { Reco.N\&P } \\
+\mathrm{KCl} \\
\text { NPSB } \\
+\mathrm{N} \text { (Urea) }\end{array}$} & Belete & 8.23 & 152.74 & 23.35 & 27.70 & 22.83 & 8.90 & 89.14 & 23.09 & 31.47 & 26.34 \\
\hline & Gudenie & 10.09 & 99.49 & 22.24 & 21.32 & 16.95 & 9.74 & 67.32 & 21.30 & 27.10 & 23.79 \\
\hline & Belete & 9.01 & 62.23 & 23.63 & 28.39 & 24.33 & 8.67 & 89.01 & 23.07 & 31.40 & 26.80 \\
\hline & Gudenie & 9.22 & 143.61 & 22.03 & 20.61 & 16.94 & 9.97 & 64.06 & 21.96 & 27.02 & 23.56 \\
\hline \multicolumn{2}{|l|}{$\mathrm{Cv}(5 \%)$} & 23.71 & 24.07 & 9.1 & 19.65 & 23.84 & 62.56 & 18.88 & 25.65 & 14.45 & 17.77 \\
\hline \multicolumn{2}{|l|}{ P-value } & NS & 0.0009 & NS & 0.005 & 0.014 & NS & NS & 0.002 & 0.04 & 0.044 \\
\hline
\end{tabular}

$A T N=$ Average tuber number; ATW=Average tuber weight in $\mathrm{g} /$ tuber; DM= Dry matter in \%; $\mathrm{TY} \mathrm{t} / \mathrm{ha}=\mathrm{Total}$
tuber yield ton per hectare; MY t/ha= Marketable tuber yield ton per hectare; $C V=$ coefficient of variation and $N S$ $=$ not significantly different

The marketable yield advantage obtained due to the application of fertilizer over the control (With no lime and no fertilizer) was $195.80 \%$ under unlimmed and over the control (With lime and no fertilizer) $71.94 \%$ under limed soil conditions. The advantage of liming was $107 \%$ in Jeldu location. On the other hand, Wenchi location provided the highest yield at application of recommended urea and DAP under both soil conditions and the yield advantage under unlimmed soil condition was 198.66 and 163.60 under limed soil condition over the control. Liming provided a yield advantage of $39 \%$ in Wenchi location. The $21.16 \mathrm{t} /$ ha highest marketable yield was obtained from Gumer location at application of NPSB and Urea under unlimmed while the highest $22.75 \mathrm{t} / \mathrm{ha}$ marketable yield was recorded from limed soil condition at application of Recommended urea and DAP. The yield increment due to application of the fertilizers under unlimmed was 50.82 and under limed was $103.31 \%$. The advantage in yield gained due to application of lime was-19\%. The highest yield produced from interaction of location and variety was provided by Belete and Gudenie grown at Wenchi while the minimum was Belete grown at Jeldu and Gudenie grown at Gumer. The interaction of the fertilizer and variety was also significant under both soil conditions (Table 5). The highest yield was produced by Belete at application of NPSB while the lowest was provided by Gudenie grown without fertilizer application under unlimmed soil condition while Belete grown at application of recommended urea and DAP was maximum under limed.

\section{DISCUSSION}

Fertilizer sources have a great impact on potato yield and yield components. Many Authors reported fertilizer source significant effect on potato yield. In this experiment, there was observed significant effect of different potassium fertilizer sources and NP sources under limed and unlimed soil condition when compared with the control (no fertilizer and lime; and no fertilizer + lime). The fertilizer sources showed 51.91-53.18\% yield increase over the control (without fertilizer) in unlimmed soil condition while 45.77-47.43\% yield increase over lime only under limed soil condition. These results are in agreements with Salunkhe et al. (1991) in which there were fertilizer management significant influence was reported on the chemical and nutritional composition of plants in addition to their anatomical and morphological structure. According to Makaraviciutte (2003), the types of fertilizer, forms, rates and their combined application can increase or decrease dry matter, starch, protein and sugar contents in potato tubers. In contrary to these results in which the potassium sourced from sulfate and chloride effects were not significantly different from NP supplied in the form of Urea and DAP as well as the blended fertilizer(NPSB), Zameer et al, (2010) reported potassium applied from both sulfate and chloride provided significantly higher tuber yield than NP. In this experiment, under unlimited soil condition, potassium chloride showed not significantly different yield increase of $2.65 \%$ over NP fertilizers sourced from Urea and DAP(recommended fertilizer application) while potassium sulfate provided $0.4 \%$. Under limed soil condition, the potassium fertilizer sources showed a yield reduction percentage of 2.9 and 2.87 compared to recommended urea and DAP. These results were in agreement with (Panique, et al, 1997, Zameer et al., 2010) in which not statistically different total tuber yield were recorded from $\mathrm{K}_{2} \mathrm{SO}_{4}$ and $\mathrm{KCl}$ sources of $\mathrm{K}$ fertilizer in five site-years. In contrary to these results, Geremew et al. (2015) combined over years and sites results showed that the highest potato tuber yield and number of tubers per meter square was obtained from the plots that received $75 \mathrm{~kg} / \mathrm{ha} \mathrm{K}_{2} \mathrm{O}$ from $\mathrm{K}_{2} \mathrm{SO}_{4}$ when compared to $\mathrm{KCl}$. They also mentioned that both types of $\mathrm{K}$ fertilizers and all $\mathrm{K}$ rates gave significantly higher tuber yields as compared to the recommended rate of NP. In agreement with this experiment, Allison et al. (2001) indicated the optimal k-rate application did not affect potato dry matter concentration. Potassium rates 
obtained from sulfate produced significantly different yield and yield component than chloride (Ismail, 2009). In line with this, the increase in tuber yields of 19,28 and 32 percent at 50,100 and $150 \mathrm{~kg} \mathrm{~K} \mathrm{~K}_{2} \mathrm{O} / \mathrm{ha}$, respectively over the control was mentioned in (Singh and Lal, 2012). These results were in conformity with the findings of Wassie and Tekalign (2013). In addition, Wassie and Shiferaw (2011) mentioned supplementation of K increased potato tuber yields by $197 \%$ over the standard N-P recommendation alone on acidic soil. This is due to soil and climatic condition difference, as well as variety and management, applied. The Authors pooled data indicated that both types of $\mathrm{K}$ fertilizers and all $\mathrm{K}$ rates gave significantly greater tuber yields compared to the recommended rate of NP.

In this experiment, treatment lime only effects provided yield increase of $27.53 \%$ over unlimed soil condition without fertilizer. This indicated that liming made some plant nutrients available for plants use which could be resulted in the yield increase. These results were in conformity with the findings of Wassie and Tekalign (2013); and Patricia and Bansal (1999). But in contrary, yields of potato tubers were generally unaffected by liming (Maier et al., 1996). Potassium is particularly important in helping plants adapt to environmental stress such as drought, improved winter hardiness and confer plants tolerance to frost, diseases and insect pests (Brady \& Weil, 2002). Thus, its deficiency in the soil causes the serious reduction in crop yield and crops encountered with K deficiency become easily susceptible to disease and pests, damage by frost and have poor yield and quality (Umar \&Moinuddin, 2001). Increasing nitrogen level up to $110 \mathrm{~kg} \mathrm{~N} /$ ha leads to more tuber yield, highest stem number, plant height, total dry biomass, total tuber number, large-sized tuber yield $(59.01 \%)$ and marketable tuber yield( Alemayehu et al., 2015). In an experiment done in growing potato under unlimmed and limed treatments of eight coarse textured soils, with initial $\mathrm{pH}$ values ranging from 4.62 to $5.02\left(\mathrm{H}_{2} \mathrm{O}\right)$ and 4.32 to $4.76(0.01 \mathrm{M}$ $\mathrm{CaCl} 2)$, in a greenhouse experiment, liming at $8 \mathrm{~g} \mathrm{CaCO} 3 / 8$ liter soil $(2,000 \mathrm{~kg} / \mathrm{ha})$ increased the average tuber yield of three soils by $40 \%$ while not significant yield difference was produced by liming soils which had $\mathrm{pH}$ values higher than $4.6(0.01 \mathrm{M} \mathrm{CaCl} 2)$ or $4.9\left(\mathrm{H}_{2} \mathrm{O}\right)$ ( van Lierop et al., 1982). According to Bolton (2009) in the investigation done within the range4-7 $\mathrm{pH}$, without added $\mathrm{P}$ and $\mathrm{Mg}$, yields of potatoes were much smaller on the more acid soils, but without K, yields were larger. Chew et al. (1981) found that increased liming favored the growth of aerial parts to the detriment of tuberization of the cassava plant. Maximum yields of potatoes were obtained at a soil $\mathrm{pH}$ of 3.4-3.6 (4-6 t lime/ha rate) but harvest index of potato tubers (mass of tubers as percent of total dry matter produced) indicated that the 10-t/ha rate would be more suitable (Mathur and Levesque, 1983). The authors also observed that plant N-P-K concentration is decreasing with increasing liming. Compared with potassium sulfate, potassium chloride resulted in higher potassium, calcium and chloride concentrations and lower sulfur concentrations. According to Lee and MacDonald (1977) raising soil pH from 4.6 to either 4.9 or 5.2 with dolomitic limestone increased tuber yield and improved tuber quality. Super phosphate applied alone or in combination with dolomitic limestone also increased tuber yield. In the glasshouse experiments, total yields of leaves, stems and haulms, the number of tubers per plant and tuber yield were not significantly affected by the application of lime while plant height was increased(Maier et al.,2002).According to (Wassie et al., 2009)application of lime along with NPK fertilizers has significantly increased the tuber yield of potato. The authors' also mentioned lime application alone did not increase the tuber yield of potato on farmers' field in contrary to this experiments result in which limed soil conditions provided $15.78 \%$ marketable yield increase over the unlimmed soil condition. This result is in disagreement with findings of Wassie and Shiferaw (2009) in which the lime application alone did not significantly increase the yield of crops in their experimental locations unless it is applied along with organic or inorganic fertilizers due to severe nutrient depletions. Zhao et al. (2007) studied the effect of $\mathrm{P}, \mathrm{K}$ and lime application on pasture and reported that $\mathrm{K}$ had no effect when applied alone but significantly increased pasture yield when applied with P. They further reported that lime had no effect on the yield of pasture. Although not many studies have been conducted so far in the country, recent work conducted by Abiye et al. (2004); Geremew et al. (2015) and Shunka et al. (2016) in highlands of Ethiopia has proved the advantage of potassium fertilizer application on wheat and potato yield increase indicating that $\mathrm{K}$ is becoming critical in some Ethiopian soils in relation with increasing soil acidity over the successive growing year. Increased yield of potato due to the application of $\mathrm{K}$ on acidic soils was also reported in Pakistan (Khandakhar et al., 2004) and Nepal (Adhikary and Karki, 2006).

\section{CONCLUSION}

Like other experiments conducted under limed and un limed soil conditions results, this experiment results can be concluded as under unlimmed and limed condition, the interaction of location and fertilizer types was highly significant in affecting total tuber number and weight, marketable tuber weight while significantly affected marketable tuber weight in $\mathrm{t} / \mathrm{ha}$. The Blended NPBS was found superior in Welmera location producing maximum total tuber yield of $33.21 \mathrm{t} / \mathrm{ha}$ under un limed soil condition, while recommended Urea and DAP provided maximum total tuber yield $31.38 \mathrm{t} /$ ha under limed soil condition. In Jeldu growing location, the recommended urea and DAP with $\mathrm{KCl}$ did produce maximum total tuber yield $(19.13 \mathrm{t} /$ ha under unlimmed; and $23.9 \mathrm{t} / \mathrm{ha}$ total tuber yield under limed soil condition). In Wenchi, the recommended urea and DAP produced a maximum of 25.66 and 
$30.99 \mathrm{t} / \mathrm{ha}$ total tuber yield under un-limed and limed soil condition, respectively. The Blended NPBS was found superior in Gumer location producing maximum total yield of $22.93 \mathrm{t} / \mathrm{ha}$ under un limed soil, while recommended Urea and DAP provided maximum total tuber yield $24.06 \mathrm{t} / \mathrm{ha}$ under limed soil condition. From these results, it can be concluded that the growing location and fertilizer sources had significantly affected the yield and yield component of potato both under limed and unlimmed soil conditions. It is better to use Blended fertilizes NPSB under unlimmed soil condition of Welmera and Gumer while recommended urea and DAP under limed soil conditions of the same location. In case of Jeldu, urea and DAP plus $\mathrm{KCl}$ is found better for production of potato while in Wenchi only recommended urea and DAP.

\section{ACKNOWLEDGEMENT}

I express my thanks to BMZ for providing the fund and farmers who hosted the experiments. I also extend my thanks to Potato research program technicians who helped during planting, crop managements and data gathering.

\section{REFERENCE}

Abiye Astatike, Mohammed Jabbar, M. A. Mohammed Salem and Teklu Erkossa, 2001. Performance of minimum tillage with animal drawn implements on vertisol management in Ethiopia. In: Advances in vertisol management in Ethiopian highlands. EARO, Addis Ababa, Ethiopia. pp. 115-125.

Abiye Astatke, TekalignMamo, Peden D. and Diedhiou M.2004: Participatory On-farm

conservation tillage trial in Ethiopian highland vertisols: The impact of potassium application on crop yield. Experimental Agriculture 40:369-379.

Adhikary B H and Karki B.2006: Effect of potassium on potato tuber production in acid soils of melapatanPokhara. Nepal Agri . Res. J. 7: 42-48.

Abayneh, E. 2001, December). Application of Geographic Information System (GIS) for soil resource study in Ethiopia. In Proceedings of the National Sensitization Workshop on Agro metrology and GIS (pp. 17-18).

Alemayehu Tilahun Getie, NigussieDechassa, TamadoTana. 2015. Response of Potato

(SolanumtuberosumL.) Yield and Yield Components to Nitrogen Fertilizer and PlantingDensity at Haramaya, Eastern Ethiopia. Journal of Plant Sciences 2015; 3(6): 320-328. (http://www.sciencepublishinggroup.com/j/jps) doi: 0.11648/j.jps.20150306.15.

Allison, M. F , J. H. Fowler and E. J. Allen. 2001. Responses of potato (Solanumtuberosum) to potassium fertilizers. Journal of Agricultural Science. 136:407-426. DOI: https://doi.org/10.1017/S0021859601008863.

Asgelil D, Taye B, Yesuf A. 2007. The status of Micro nutrients in Nitisols, Vertiso ls, Cambisols and Fluvisols in major Maize, Wheat, Teff and Citrus growing areas of Ethiopia. In: Proceedings of Agricultural Research Fund, pp 77-96.

Brady, N.C. and R.R. Weil, 2002. The Nature and Properties of Soil, $13^{\text {th }}$ edition. Prentice Hall, New Jersey .

Bolton .J. 2009. Liming effects on the response of potatoes and oats to phosphorus, potassium and magnesium fertilizers. 89(1): 87-93. DOI: https://doi.org/10.1017/S0021859600027222.

Chew, W. Y., Joseph, K. T., Ramli, K. And Majek, A. B. A. 1981. Influence of lim-ing and soil pH on Cassava (Manihotesculenta) in a tropical oligotrophic peat. Exp. Agric. 17:171-178.

CSA(Central Statistical Agency). 2006. The Federal Democratic Republic of Ethiopia. Agricultural Sample Survey Report of 2007. Statistical Report on Farm Management Practices Private Peasant holdings, Meher season, 3:17-19.

CSA(Central Statistical Agency). 2016. The Federal Democratic Republic of Ethiopia. Agricultural Sample Survey Report of 2017. Statistical Report on Farm Management Practices Private Peasant holdings, Meher season, 3:17-19.

Dkhil, B. B., Denden, M., \& Aboud, S. 2011. Foliar potassium fertilization and its effect on growth, yield and quality of potato grown under loam-sandy soil and semi-arid conditions. International Journal of Agricultural Research,6(7), 593-600.

FAO,2008. Agriculture Rome, Available in http://faostat.fao.org/ faostat/collections? Subset agriculture.Accessed on 1 April 2008.

Gebremedhin W, Hailemariam G, Lemaga B, Schulz S. 2015. Quality Seed Potato Production: Experience From the Highlands of Ethiopia. Potato and Sweetpotato in Africa: Transforming the Value Chains for Food and Nutrition Security. 2015 Oct 28:186.

GeremewTayeAyalew Adela GetachewAlemu. 2015. Response of Potato(Solanumtuberosum L.) to Potassium Fertilizer on Acid Soils of Wolmera and GumerWeredas, in the High Lands of Ethiopia. Journal of Biology, Agriculture and Healthcare www.iiste.org.

Ismail A. I. Abu-Zinada. 2009. Potato Response to Potassium and Nitrogen Fertilization Under Gaza Strip Conditions. Journal of Al Azhar University-Gaza (Natural Sciences),11:15-30.

Kamprath, E.J., 1984. Crop response to lime on soils in the tropics. Soil acidity and liming, (soilacidityandl), pp.349-368 
Khandakhar SMA, Rahman T, Uddin MM, Khan MJ, SAK and Quddus KJ. 2004. Effect of lime and potassium on potato yield in acid soil. Pakistan J. Biol. Scie. 7: 380-383.

Lee, C. R., and M. L. MacDonald. 1977. Influence of Soil Amendments on Potato Growth, Mineral Nutrition, and Tuber Yield and Quality on Very Strongly Acid Soils1. Soil Sci. Soc. Am. J. 41:573-577. doi:10.2136/sssaj1977.03615995004100030030.

Maier, N. A, McLaughlin,M. J, Heap,M, Butt,M., Smart.M. K. and Williams,C. M. J. 1996. Effect of currentseason application of calcitic lime on soil $\mathrm{pH}$, yield and cadmium concentration in potato (Solanumtuberosum L.) tubers. February 1996, Volume 47, Issue 1, pp 29-40.

Maier, N. A, McLaughlin,M. J, Heap,M, Butt,M. and Smart.M. K. 2007. Effect of current-season application of calcitic lime and phosphorus fertilization on soil $\mathrm{pH}$, potato growth, yield, dry matter content, and cadmium concentration. Communications in Soil Science and Plant Analysis. 33(13-14): 2145-2165. http://dx.doi.org/10.1081/CSS-120005754.

Maier, N.A., McLaughlin, M.J., Heap, M., Butt, M. and Smart, M.K., 2002. Effect of current-season application of calcitic lime and phosphorus fertilization on soil $\mathrm{pH}$, potato growth, yield, dry matter content, and cadmium concentration. Communications in Soil Science and Plant Analysis, 33(13-14), pp.2145-2165.

Makaraviciutte, A. 2003. Effects of organic and mineral fertilizers on the yield and quality of deferent potato varieties. Agronomy Research, 1(2):197-209.

Mathun, S. P. and Levesque, M. P. 1983. Effect of liming on the yield, nutrition and copper status of potatoes, carrots and onions grown sequentially in two peat soils. Can. J. Soil Sci. 63:229-244.

Merga Hillel, 2004. Potassium in Fertigation systems. $5^{\text {th }}$ Fertigation training course Baoding AUH, June 2004.International Potash Institute(IPI), P.O.BOX 1609, Basel Switzerland, 1-13.

Panique, E., K.A. Kelling, E.E. Schulte, D.E. Hero, W.R. Stevenson and R.V. James, 1997. Potassium rate and source effects on potato yield, quality, and disease interaction. Amarican Potato J., 74: 379-398.

Patricia Imas and S.K. Bansal. 1999. Potassium and Integrated Nutrient Management in Potato. Presented at the Global Conference on Potato. 6-11 December 1999, New Delhi, INDIA.

Sanchez Pedro A, 2000. Linking climate change research with food security and poverty reduction in the tropics. Agriculture, Ecosystems \& Environment, Volume 82, Issues 1-3, December 2000, Pages 371-383.

Salunkhe, D.K., Bolin, H.R. and Reddy, N.R. 1991. Storage, processing and nutritional quality of carrots and vegetables. 2 nd eds. 1:7-20.

Singh, S.K. and Lal, S.S. 2012. Effect of potassium levels and its uptake on correlation between tuber yield and yield attributing characters in potato (SolanumtuberosumL.) var. KUFRI PUKHRAJ, Asian J. Hort., 7(2): 392-396.

Shunka E, Chindi A, W/giorgis G, Seid E, Tessema L.2016. Response of Potato (Solanumtuberosum L.) Varieties to Nitrogen and Potassium Fertilizer Ratesin Central Highlands of Ethiopia. Adv Crop Sci Tech 4: 250. doi: 10.4172/2329-8863.1000250.

Umar, S. and Moinuddin, 2001. The effect of sources and rates of potasium application on potato yield and ecconomic returns. Better Crop Int., 15: 13-15.

Van Lierop, W., T. S. Tran, G. Banville, and S. Morissette. 1982. Effect of Liming on Potato Yields as Related to Soil pH, Al, Mn, and Ca1. Agron. J. 74:1050-1055. doi:10.2134/agronj1982.00021962007400060028x.

Wassie Haile and Shiferaw Boke. 2009. Mitigation of soil acidity and fertility decline challenges for sustainable livelihood improvement: Evidence from southern Region of Ethiopia. PP.131- 143. In: Atlaw A., Saba Y., Alemu M. and Minale K. (eds.). Proceedings of the national Conference on Sustainable Land Management and Poverty Alleviation, Co-organized by Environmental Economics Policy Forum for Ethiopia at Ethiopian Development Research Institute, Sustainable Land Use Forum (SLUF), Oromia Agricultural Research Institute (ORARI) and College of Agriculture at Hawassa University, Addis Ababa, December, 2009.

Wassie Haile and Shiferaw Boke .2011. Response of Irish Potato (Solanumtuberosum) to the application of Potassium at Acidic Soils of Chencha, Southern Ethiopia. International Journal of Agricultural Biology 13: 595-598.

Wassie Haile and TekalignMamo, 2013. The Effect of Potassium on the Yields of Potato and Wheat grown on the Acidic Soils of Chencha and HagereSelam in Southern Ethiopia. International Potash institute.

Wassie Haile, Shiferaw Boke and KelsaKena .2009. Integrated soil fertility management options for Sustainable Crop Production:Review of Research Findings from Southern Regional State of Ethiopia. Paper presented on the 10th anniversary conference of Ethiopian Society of Soil Science (ESSS), 26-27 March 2009, Addis Ababa, Ethiopia.

Zakri, M. and T. A. Obreza, 2009. Plant Nutrient for Citrus trees. SL 200, UF/IFAS Extension Service, Institute of Food and Agricultural Sciences, University of Florida.

Zameer Khan, M, Ehsan Akhtar,M, NaeemSafdar, M,MasudMahmood,M,Sagheer Ahmad and Ahmed, N. 2010. Effect of Source and Level of Potash on Yield and Quality of Potato Tubers. Pak. J. Bot ., 42(5): 3137-3145, 2010. 
Zhao J, Michalk, LY. Wen Y, Kemp KR, Du, G and Helen N. 2007. Effect of phosphorus, potassium and lime application on pasture in acidic soils in Yunnan province, China. New Zealand J. of Agri. Res., 50: 523-535. 